\title{
5. COMPUTER MODELING OF MAJOR AND TRACE ELEMENT VARIATIONS OF HOLE 504B DIABASE AND BASALT ${ }^{1}$
}

\author{
H.R. Naslund, ${ }^{2}$ J.W. Sparks,${ }^{3}$ and M.R. Fisk ${ }^{4}$
}

\begin{abstract}
Four computer modeling techniques were used to examine the intersample variation in Hole 504B basalt and diabase: (1) a liquid-line-of-descent calculation (the CHAOS program, Nielsen [1985, 1990]); (2) Pearce element ratio analysis (Pearce, 1968); (3) a least-squares-fit parent-daughter calculation (Bryan et al., 1969); and (4) correlation coefficient pattern analysis (the DARWIN program, Cox and Clifford [1982]). The first two techniques require few input assumptions, and can be used to identify what phases are fractionating, the compositions of those phases, and the relative proportions of those phases. The other two techniques require a considerable amount of input assumptions, and are primarily useful for testing petrologic models. The liquid-line-of-descent calculation suggests that fractional crystallization of plagioclase $\mathrm{An}_{74.4}$, augite $\mathrm{Wo}_{41.7} \mathrm{En}_{48.6} \mathrm{Fs}_{9.7}$, and olivine $\mathrm{Fo}_{85.3}$ from an initial mid-ocean-ridge basalt parent could explain the range of compositions observed in the 504B data set. The complementary gabbro would have the cumulus mineral assemblage $57.5 \%$ plagioclase, $23.3 \%$ augite, and $19.3 \%$ olivine plus an unknown amount of intercumulus liquid. Pearce element ratio analysis suggests that fractional crystallization of plagioclase $\mathrm{An}_{79-86}$, augite $\mathrm{Mg}_{82-83}$, and olivine $\mathrm{FO}_{78-79}$ could explain the range of compositions observed in the 504B data set. The complementary gabbro would have a cumulus mineral assemblage of $62 \%$ to $67 \%$ plagioclase, $23 \%$ to $27 \%$ augite, and $8 \%$ to $12 \%$ olivine plus an unknown amount of intercumulus liquid. All four computer models are consistent with a differentiation scheme for 504B magmas in which an initial high $\mathrm{Mg \#}$ parent fractionates plagioclase, augite, and olivine to produce a series of daughter magmas with lower Mg\#s. None of the models require significant amounts of assimilation or more than one parent magma composition to explain the variation observed in the 504B data. Fraction of the observed $1726 \mathrm{~m}$ of basalt and diabase at Site 504B would require a minimum thickness of $573 \mathrm{~m}$ of gabbro if we assume $0 \%$ trapped liquid, or $1042 \mathrm{~m}$ of gabbro if we assume $45 \%$ trapped liquid. The lower crustal section at Hole 504B is probably thicker and more primitive than that calculated.
\end{abstract}

\section{INTRODUCTION}

The development of modern automated equipment for the analysis of whole-rock samples allows petrologists to collect larger, more complete, and more accurate data sets than were possible using wetchemical methods. A number of computer methods have been developed to model the intersample variation observed in these extensive data sets. We have applied four of these techniques to basalt and diabase analyses from Hole 504B: (1) a liquid-line-of-descent calculation (the CHAOS program, Nielsen [1985, 1990]); (2) Pearce element ratio analysis (Pearce, 1968); (3) a least-squares-fit parent-daughter calculation (Bryan et al., 1969); and (4) correlation coefficient pattern analysis (the DARWIN program, Cox and Clifford [1982]). Each of these methods requires the user to make some assumptions about the differentiation process, and then provides a set of relationships compatible with those assumptions. In addition to comparing these four methods, and trying to determine how the 504B magmas differentiated, the models generated by these methods can be used to predict the composition of the gabbros that might be encountered at depth in Hole 504B as a complement to the basalts and diabases recovered to date.

More than 500 whole-rock analyses have been made of Hole 504B basalts and diabases from the $1726 \mathrm{~m}$ of igneous core recovered through Leg 140. To minimize the effect of interlaboratory variations, we have selected a set of 273 X-ray fluorescence (XRF) analyses of basalts and diabases of group D composition from laboratories using similar standards and data reduction procedures (Autio and Rhodes, 1983; Kempton et al., 1985; Autio et al., 1989; Shipboard Scientific

${ }^{1}$ Erzinger, J., Becker. K., Dick, H.J.B., and Stokking, L.B. (Eds.), 1995. Proc. ODP, Sci. Results, 137/140: College Station, TX (Ocean Drilling Program)

${ }^{2}$ Department of Geological Sciences, State University of New York at Binghamton, Binghamton, NY 13902-6000, U.S.A.

${ }^{3}$ Department of Geology, Stanford University, Stanford, CA $94305-2115$, U.S.A

${ }^{4}$ College of Oceanography, Oregon State University, Corvallis, OR 97331-5503, U.S.A.
Party, 1992; Sparks, this volume). From this set of analyses, a subset of 92 aphyric to sparsely phyric samples ( $0 \%-2 \%$ phenocrysts) was selected to best represent the range of group $\mathrm{D}$ magma compositions in the 504B section (Fig. 1). Only the least altered samples $(\mathrm{Cu} \geq 45 \mathrm{ppm} ; \mathrm{Zr} / \mathrm{Y}=1.6-2.45)$ were used in this subset to minimize the effects of pervasive hydrothermal alteration (e.g., Sparks, this volume). The calculated means, standard deviations, and ranges of major element oxides and selected trace elements for this suite are presented in Table 1.

More than $98 \%$ of the analyzed basalts and diabases from Hole 504B fall in group D of Autio and Rhodes (1983). Compositionally they can be classified as olivine-normative to slightly quartznormative tholeiites with compositions similar to moderately evolved mid-ocean-ridge basalts (MORB). They are unusually depleted in incompatible elements, but have incompatible element ratios similar to those of normal MORB. Although 504B samples cover a range of differentiation $(\mathrm{Mg} \#=67.8-53.1)$, standard Harker diagrams (Fig. 2) are of limited use in determining the processes of differentiation that operated on these magmas.

\section{LIQUID-LINE-OF-DESCENT CALCULATIONS}

The availability of thermodynamic and phase equilibria data for basaltic liquids and associated liquidus minerals allows the liquidus temperature and liquidus assemblage of most basaltic compositions to be calculated with a reasonable degree of confidence. A number of programs have been written that take advantage of these calculations to determine the differentiation history or liquid-line-of-descent for a wide range of basaltic starting compositions. The user can then compare the calculated daughter-liquid compositions with the compositions of the more evolved magmas in the data set. In general, in this type of calculation a computer program is used to determine the liquidus assemblage of a given magma. The program then subtracts a small increment of that assemblage to produce a new magma composition. The program then calculates the liquidus assemblage of the 


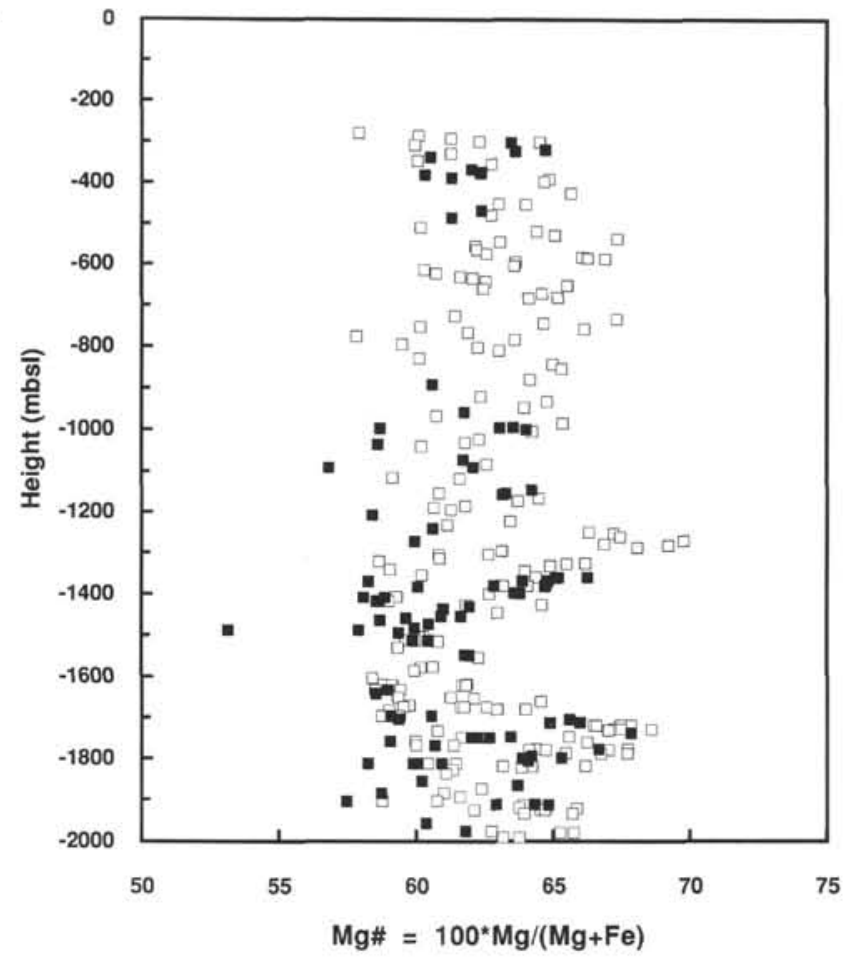

Figure 1. Selected group D MORB samples for this study. Open symbols represent 273 XRF analyses of group D samples (Autio and Rhodes, 1983; Kempton et al., 1985; Autio et al., 1989; Shipboard Scientific Party, 1992; Sparks, this volume); solid symbols represent a selected subset of 93 leastaltered, aphyric samples.

new magma and subtracts a small increment of that assemblage. By this method, the initial magma composition is incrementally crystallized, while the phases removed and the changing magma compositions are recorded.

The program CHAOS (Nielsen, 1985; 1990) has been used to determine three liquid-line-of-descent models for a typical primitive magma composition $(\mathrm{Mg \#}=62.6)$ from Hole 504B. One of the advantages to using a program like CHAOS is that the user does not have to make any assumptions about the phases that are fractionated. Users need only to input the composition of the parent magma, the composition of any assimilant, the oxygen fugacity, whether equilibrium or fractional crystallization has occurred, a few control parameters (the calculation increment, the output increment, etc.) and data on how often and how much the differentiating magma chamber is recharged, how often and how much assimilation occurs, and how often and how much eruption occurs. The three models run for this study specified fractional crystallization with no assimilation, no recharge, no eruption, and oxygen fugacities of QFM, 1 log unit below QFM, and 1 log unit above QFM. The models were run until the resulting daughter magma had a $\mathrm{Mg}$ \# approximating that of the most evolved 504B magma.

The model run at QFM calculates a daughter magma with a Mg\# $=52.9$ after $30.1 \%$ crystallization of olivine $\mathrm{Fo}_{85.3}(5.8 \%)$, augite $\mathrm{Wo}_{41.7} \mathrm{En}_{48.6} \mathrm{Fs}_{9.7}(7.0 \%)$, and plagioclase $\mathrm{An}_{74.4}$ (17.3\%) (Table 2). The model predicts that olivine + plagioclase would be the initial liquidus phases $(0 \%-15 \%$ crystallization), followed by plagioclase + augite + olivine $(15.1 \%-30.1 \%$ crystallization). The model run at 1 log unit below QFM predicts slightly more olivine (6.1\%) and slightly less augite $(6.7 \%)$ but otherwise produced similar results. The model run at $1 \log$ unit above QFM calculated slightly less olivine $(5.4 \%)$ and slightly more augite $(7.4 \%)$ but otherwise produced similar results. These three models suggest that the gross variation seen in the 504B magmas can be explained by shallow (crustal level) crystal-
Table 1. Means, standard deviations, and ranges of major elements and selected trace elements in 92 aphyric to sparsely phyric samples, Hole 504B.

\begin{tabular}{lcccc}
\hline & Mean & Std. dev. & Min. & Max. \\
\hline $\mathrm{SiO}_{2}(\%)$ & 50.2 & 0.5 & 48.5 & 51.1 \\
$\mathrm{TiO}_{2}$ & 0.96 & 0.11 & 0.71 & 1.24 \\
$\mathrm{Al}_{2} \mathrm{O}_{3}$ & 15.15 & 0.71 & 13.80 & 16.90 \\
$\mathrm{Fe}_{2} \mathrm{O}_{3} *$ & 10.45 & 0.72 & 8.83 & 12.50 \\
$\mathrm{MnO}$ & 0.18 & 0.02 & 0.15 & 0.26 \\
$\mathrm{MgO}$ & 8.42 & 0.43 & 7.16 & 9.57 \\
$\mathrm{CaO}$ & 12.76 & 0.35 & 11.69 & 13.27 \\
$\mathrm{Na}_{2} \mathrm{O}$ & 1.96 & 0.17 & 1.59 & 2.51 \\
$\mathrm{~K}_{2} \mathrm{O}$ & 0.03 & 0.06 & 0.00 & 0.36 \\
$\mathrm{P}_{2} \mathrm{O}_{5}$ & 0.07 & 0.02 & 0.04 & 0.13 \\
$\mathrm{Zr}(\mathrm{ppm})$ & 48 & 6 & 35 & 64 \\
$\mathrm{Y}$ & 25 & 2 & 20 & 30 \\
$\mathrm{Sr}$ & 57 & 8 & 43 & 78 \\
$\mathrm{Ni}$ & 102 & 23 & 55 & 164 \\
\end{tabular}

Note: $\mathrm{Fe}_{2} \mathrm{O}_{3}$ * is total iron as $\mathrm{Fe}_{2} \mathrm{O}_{3}$.

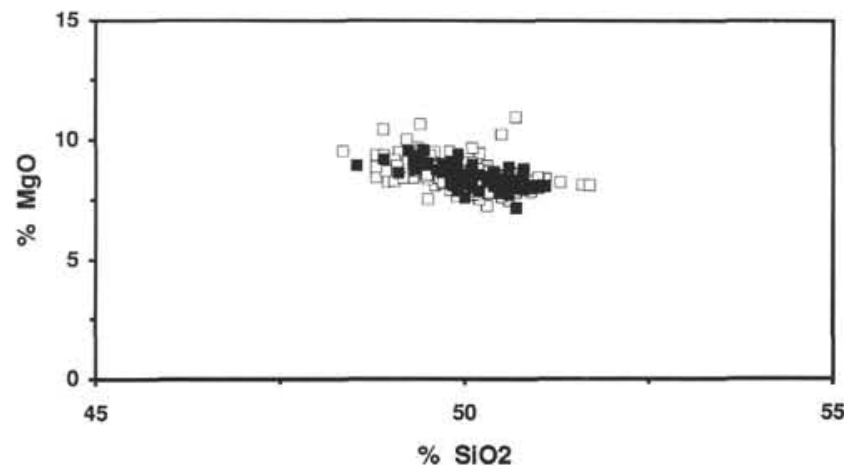

Figure 2. Harker plot of $\% \mathrm{MgO}$ vs. $\% \mathrm{SiO}_{2}$ for the samples used in this study. Symbols as in Figure 1.

lization of plagioclase, augite, and olivine from an initial MORB parent. The complementary gabbro would have the cumulus mineral assemblage $57.5 \%$ plagioclase, $23.3 \%$ augite, and $19.3 \%$ olivine plus an unknown amount of intercumulus liquid. A number of more complex models could be run using CHAOS to better fit the major and trace element compositional variation in the 504B data set (Fisk et al., 1992), but that is beyond the scope of this paper.

\section{PEARCE ELEMENT RATIO ANALYSIS}

Pearce element ratio analysis (Pearce, 1968, 1990; Nichols and Russell, 1990) can be applied easily to a data set using any advanced spreadsheet-plotting program on a personal computer. The technique first converts analyses to cation percents, and then plots various ratios of petrologic interest. In general, a conserved element (i.e., one that does not enter any of the fractionating phases and has not been mobilized during alteration) is used as the denominator. Plots of excluded element ratios can be used to identify co-genetic suites because ratios of excluded elements remain constant during fractional crystallization. Plots of included elements divided by a common conserved element can be used to identify fractionated mineral phases, because cation ratios have predictable variation patterns for each fractionated mineral. For example, if olivine, $(\mathrm{Mg}, \mathrm{Fe})_{2} \mathrm{SiO}_{4}$, is fractionated, the change in $\mathrm{Fe}+\mathrm{Mg}$ will be twice that of the change in $\mathrm{Si}$, so that a plot of $(\mathrm{Fe}+$ $\mathrm{Mg}) / \mathrm{Zr}$ vs. $\mathrm{Si} / \mathrm{Zr}$ will have a slope of 2.0 if olivine is the only fractionated phase. The use of cation ratios, instead of weight percent (wt\%) variations, results in plots that are not sensitive to the addition or subtraction of elements that do not appear in the plots (this is particularly useful in working with data sets in which the user suspects that 
Table 2. Output from the three CHAOS models run with a single 504B composition.

\begin{tabular}{lccc}
\hline & QFM & QFM +1 & QFM - 1 \\
\hline Parent Mg\# & 62.7 & 62.7 & 62.7 \\
Parent liquidus $\left({ }^{\circ} \mathrm{C}\right)$ & 1203 & 1216 & 1203 \\
Daughter Mg\# & 52.9 & 52.8 & 52.8 \\
Daughter liquidus $\left({ }^{\circ} \mathrm{C}\right)$ & 1179 & 1180 & 1177 \\
Total \% fractionation & 30.1 & 30.1 & 30.1 \\
\% olivine fractionation & 5.8 & 6.1 & 5.4 \\
Olivine/total crystals & 0.193 & 0.203 & 0.179 \\
Average olivine (Fo\%) & 85.3 & 84.7 & 86.4 \\
\% plagioclase fractionation & 0.575 & 0.575 & 0.575 \\
Plagioclase/total crystals & 17.3 & 17.3 & 17.3 \\
Average plagioclase (An\%) & 74.4 & 74.5 & 74.3 \\
\% augite fractionation & 7.0 & 6.7 & 7.4 \\
Augite/total crystals & 0.233 & 0.223 & 0.246 \\
Average augite (Wo:En:Fs) & $42: 49: 10$ & $42: 48: 10$ & $42: 49: 9$ \\
Average augite Mg\# & 83.4 & 82.7 & 84.4 \\
\hline
\end{tabular}

one or more elements have been mobilized during alteration). An additional advantage of applying Pearce element ratio analysis to large data sets is that all of the analyses in the data set are used to determine the final fractionation model. Like the CHAOS model described above, Pearce element ratio analysis does not require any assumptions about the phases that are fractionated, only some basic assumptions about whether the data set is the result of fractional crystallization or assimilation, and whether the data set represents a co-genetic suite. The Pearce element plots in this paper are based on the two data sets described above with open symbols used for the set of 273 group D analyses and filled symbols used for the subset of 92 least-altered aphyric samples. All of the calculated slopes are based on the subset of 92 aphyric samples; for each calculated slope the correlation coefficient $(R)$ for the best-fit regression line and the $95 \%$ confidence limits on the slope are also given.

On a plot of Y/Ti vs. Zr/Ti (Fig. 3A) the 504B samples form a tight cluster, indicating that $\mathrm{Ti}, \mathrm{Y}$, and $\mathrm{Zr}$ are conserved elements in this suite, and that the samples represent a series of magmas that, if not comagmatic, have had similar histories during partial melting, transport, and differentiation. On a plot of P/Ti vs. K/Ti (Fig. 3B) the spread of values indicates that $\mathrm{K}$ (and to a lesser extent $\mathrm{P}$ ) does not behave as a conserved element in this suite.

A plot of $\mathrm{F}^{\prime} / \mathrm{Ti}$ vs. $\mathrm{Si} / \mathrm{Ti}$ (where $\mathrm{F}^{\prime}=0.5 \cdot(\mathrm{Fe}+\mathrm{Mg})+2 \cdot \mathrm{Ca}+3$. $\mathrm{Na}$ ) can be used to test a simple model that postulates that intersample variation in this suite is the result of the crystallization of olivine, augite, and plagioclase. The formula for $\mathrm{F}^{\prime}$ was selected so that its value for olivine $\left(\left[\mathrm{Fe}, \mathrm{Mg}_{2} \mathrm{SiO}_{4} ; \mathrm{F}^{\prime}=1\right)\right.$, augite $\left(\mathrm{Ca}_{0.67}[\mathrm{Fe}, \mathrm{Mg}]_{1.33} \mathrm{Si}_{2} \mathrm{O}_{6} ; \mathrm{F}^{\prime}\right.$ $=2)$, anorthite $\left(\mathrm{CaAl}_{2} \mathrm{Si}_{2} \mathrm{O}_{8} ; \mathrm{F}^{\prime}=2\right)$, or albite $\left(\mathrm{NaAlSi}_{3} \mathrm{O}_{8} ; \mathrm{F}^{\prime}=3\right.$ ) will be equal to the number of $\mathrm{Si}$ cations in the mineral. On a plot of $\mathrm{F}^{\prime} / \mathrm{Ti}$ vs. Si/Ti (Fig. 4A) the addition or subtraction of olivine, augite, or plagioclase in any proportions will result in a line with a slope of 1.0 , while the addition or subtraction of orthopyroxene will result in a line with a slope of 0.5 , and the addition or subtraction of any Si-free and Ti-free oxide (chromite, magnetite) will result in a trend with a slope of $\infty$. The 504B data yield a slope of $1.044(R=0.983 ; \pm 95 \%=1.004$ to 1.084) confirming that orthopyroxene and Fe-oxides are not important fractionating phases in these rocks. The slightly higher than expected slope may be the result of the fact that the calculation assumed an augite composition of $\mathrm{Ca}_{0.67}(\mathrm{Fe}+\mathrm{Mg})_{1.33} \mathrm{Si}_{2} \mathrm{O}_{6}$. An augite composition of $\mathrm{Ca}_{0.80}(\mathrm{Fe}+\mathrm{Mg})_{1.20} \mathrm{Si}_{2} \mathrm{O}_{6}$ would result in a slope of 1.10 . The crystallization of a typical gabbro with $10 \%$ olivine, $30 \%$ augite $\left(\mathrm{Ca}_{0.80}\right.$ $\left.(\mathrm{Fe}+\mathrm{Mg})_{1.20} \mathrm{Si}_{2} \mathrm{O}_{6}\right)$, and $60 \%$ plagioclase $\left(\mathrm{An}_{85}\right)$ would result in a slope of 1.034 , similar to that observed.

A plot of $\mathrm{F}^{\prime \prime} / \mathrm{Ti}$ vs. $\mathrm{Si} / \mathrm{Ti}\left(\right.$ where $\mathrm{F}^{\prime \prime}=\mathrm{Al}+0.5 \cdot(\mathrm{Fe}+\mathrm{Mg})-4 \cdot \mathrm{Ca}$ $-4 \cdot \mathrm{Na}$ ) can be used to separate the effects of olivine crystallization from augite and plagioclase crystallization. On such a plot (Fig. 4B) olivine crystallization will result in a line with a slope of 1.0, orthopyroxene crystallization will result in a line with a slope of 0.5 , and plagioclase or augite crystallization will result in a trend with a slope
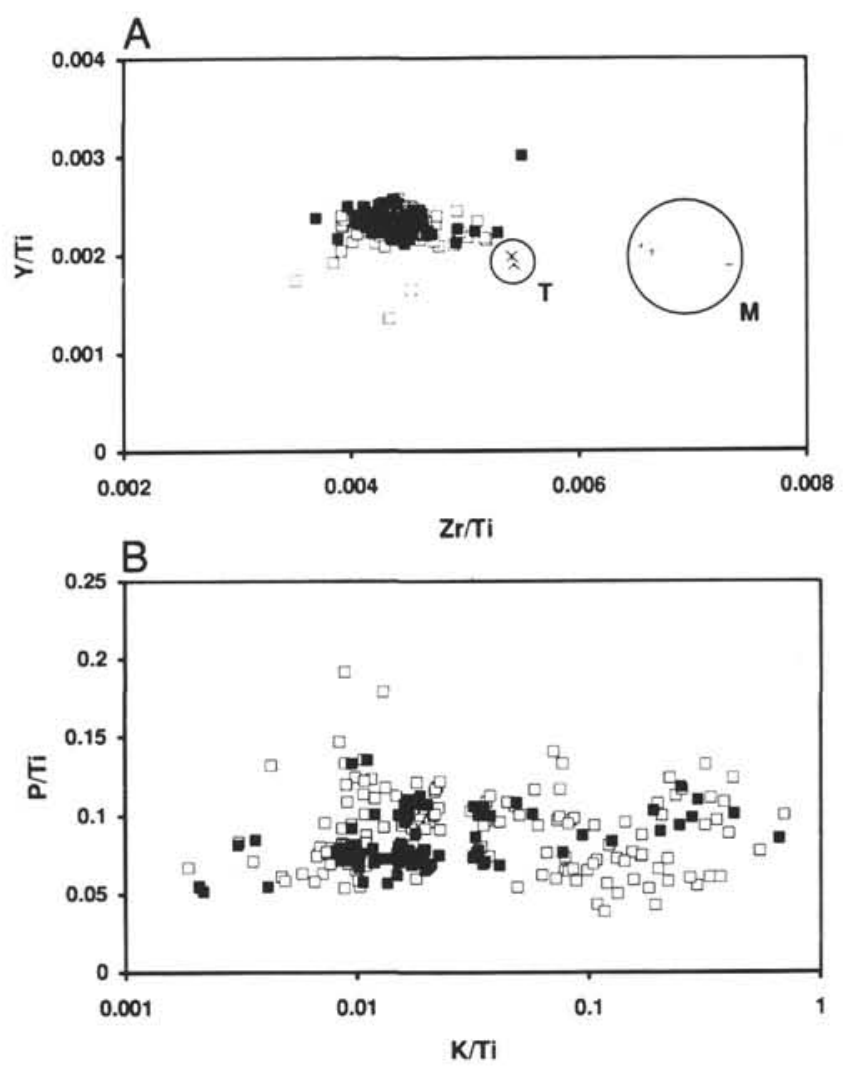

Figure 3. A. Excluded element ratio plot of 504B group D MORB. The tight clustering of group $\mathrm{D}$ samples indicates that $\mathrm{Y}, \mathrm{Zr}$, and $\mathrm{Ti}$ are all behaving as conserved elements. Symbols as in Figure 1. The fields for type T (asterisks) and type M MORB (crosses) (Autio and Rhodes, 1983) are indicated. B. Excluded element ratio plot of 504B group D MORB. The sample distribution indicates that $\mathrm{K}$, and to a lesser extent $\mathrm{P}$, are not behaving as conserved elements in this data set. Symbols as in Figure 1.

of -1.0 . The 504B data yield a slope of $-0.8165(R=0.949 ; \pm 95 \%=$ -0.7598 to -0.8732 ) confirming a model dominated by augite and plagioclase, with a small but significant olivine component.

A plot of $\mathrm{F}^{\prime \prime \prime} / \mathrm{Ti}$ vs. $\mathrm{Al} / \mathrm{Ti}$ (where $\mathrm{F}^{\prime \prime \prime}=2 \cdot \mathrm{Ca}+\mathrm{Na}$ ) can be used to separate the effects of augite and plagioclase crystallization. On such a plot (Fig. 5A) plagioclase crystallization will result in a trend with a slope of 1.0, and augite crystallization will result in a trend with a slope of $\infty$. Neither olivine nor orthopyroxene crystallization will have an effect on this diagram because neither contains significant amounts of $\mathrm{Ca}, \mathrm{Na}$, or $\mathrm{Al}$. The 504B data yield a slope of $1.386(R=0.971 ; \pm 95 \%$ $=1.314$ to 1.457 ), confirming a model with significant augite crystallization, but dominated by plagioclase crystallization. Pearce element ratios can also be used quantitatively to calculate the relative proportions of the fractionated mineral phases. On a plot of $\mathrm{Na} / \mathrm{Ti}$ vs. Al/Ti (Fig. 5B), the slope is a direct function of the composition of the average fractionated plagioclase and is independent of any other fractionated phase $($ slope $=\mathrm{Xab} /[2-\mathrm{Xab}])$ (see Appendix). The 504B data has a slope of $0.0959(R=0.683 ; \pm 95 \%=0.0744$ to 0.1174$)$, indicating an average plagioclase composition of $\mathrm{An}_{82.5}\left(\mathrm{An}_{79.0}\right.$ to $\left.\mathrm{An}_{86.2}\right)$. The low $R$ value for this plot may result from $\mathrm{Na}$ mobilization in some samples during alteration, and from the fact that a range of plagioclase compositions has crystallized from this suite.

If we assume a plagioclase composition of $\mathrm{An}_{82.5}$, we can determine the relative proportions of plagioclase and augite from the slope of $\mathrm{F}^{\prime \prime \prime} / \mathrm{Ti}$ vs. $\mathrm{Al} / \mathrm{Ti}$ (slope $=[\mathrm{Xcpx}+1.2 \cdot \mathrm{Xan}+0.6 \cdot \mathrm{Xab}] /[1.2 \cdot \mathrm{Xan}$ $+0.6 \cdot \mathrm{Xab}]$ for $\mathrm{Ca}_{0.67}[\mathrm{Fe}+\mathrm{Mg}]_{133} \mathrm{Si}_{2} \mathrm{O}_{6}$ or slope $=[1.2 \cdot \mathrm{Xcpx}+1.2$ $\cdot \mathrm{Xan}+0.6 \cdot \mathrm{Xab}] /[1.2 \cdot \mathrm{Xan}+0.6 \cdot \mathrm{Xab}]$ for $\mathrm{Ca}_{0.80}\left[\mathrm{Fe}+\mathrm{Mg}_{1.20} \mathrm{Si}_{2} \mathrm{O}_{6}\right)$ 

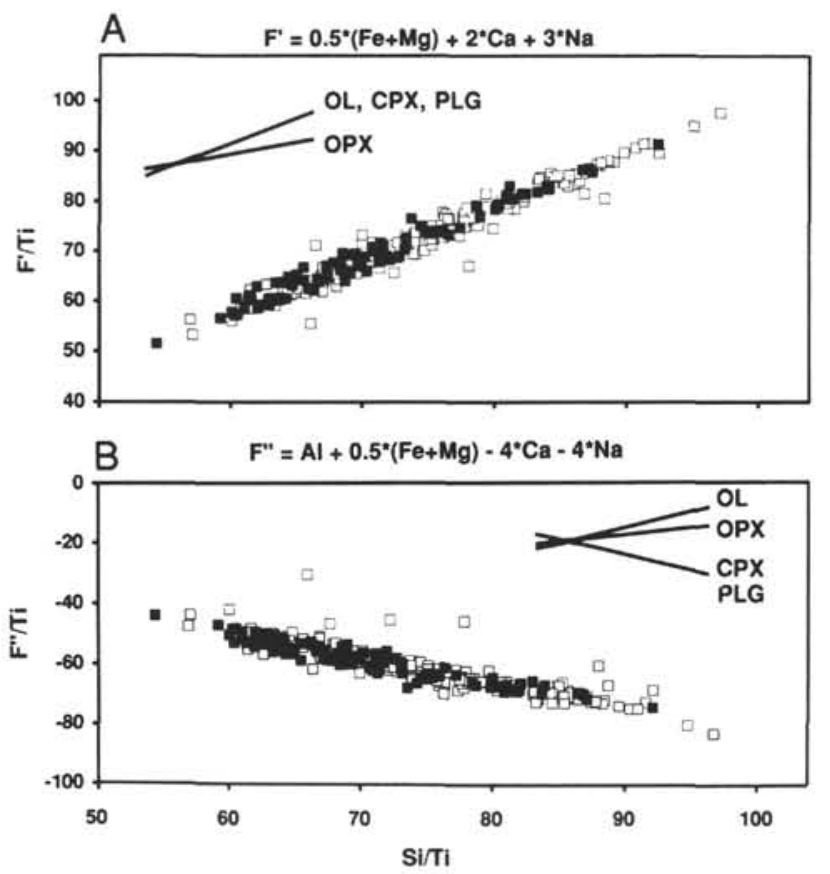

Figure 4. A. Pearce element ratio plot of 504B group D MORB samples. The fractionation of olivine (OL), augite (CPX), and plagioclase (PLG) will result in a trend parallel to a slope of 1.0 ; fractionation of orthopyroxene (OPX) will result in a trend parallel to a slope of 0.5. Symbols as in Figure 1. B. Pearce element ratio plot of 504B group D MORB samples. The fractionation of olivine (OL) will result in a trend parallel to a slope of 1.0 ; fractionation of orthopyroxene (OPX) will result in a trend parallel to a slope of 0.5 ; fractionation of augite (CPX) and plagioclase (PLG) will result in a trend parallel to a slope of -1.0 . Symbols as in Figure 1 .

(Fig. 5A). The 504B data yields an augite/(augite + plagioclase) of 0.297 (0.256 to 0.334 ) for augite with $33 \%$ Wo component and 0.260 ( 0.223 to 0.294 ) for augite with $40 \%$ Wo.

If we know the plagioclase composition and the relative proportions of augite and plagioclase (and assume orthopyroxene crystallization $=0$ ) we can determine the amount of fractionated olivine from the slope of $\mathrm{F}^{\prime \prime} / \mathrm{Ti}$ vs. Si/Ti (slope $=[\mathrm{Xol}-1.2 \cdot \mathrm{Xan}-1.8 \cdot \mathrm{Xab}$ $-1.5 \cdot \mathrm{Xcpx}] /[\mathrm{Xol}+1.2 \cdot \mathrm{Xan}+1.8 \cdot \mathrm{Xab}+1.5 \cdot \mathrm{Xcpx}]$ for $\mathrm{Ca}_{0.67}[\mathrm{Fe}$ $+\mathrm{Mg}_{1.33} \mathrm{Si}_{2} \mathrm{O}_{6}$ or slope $=[\mathrm{Xol}-1.2 \cdot \mathrm{Xan}-1.8 \cdot \mathrm{Xab}-1.95$. $\mathrm{Xcpx}] /[\mathrm{Xol}+1.2 \cdot \mathrm{Xan}+1.8 \cdot \mathrm{Xab}+1.5 \cdot \mathrm{Xcpx}]$ for $\mathrm{Ca}_{0.80}[\mathrm{Fe}+$ $\mathrm{Mg}_{1.20} \mathrm{Si}_{2} \mathrm{O}_{6}$ ) (Fig. 4B). The 504B data yields an olivine/(olivine + augite + plagioclase) of 0.121 ( 0.084 to 0.157 ) for augite with $33 \%$ Wo component and $0.130(0.091$ to 0.167$)$ for augite with $40 \%$ Wo.

An independent check of olivine/(olivine + augite) can be obtained from a plot of $(2 \cdot \mathrm{Ca}+\mathrm{Na}-\mathrm{Al}) / \mathrm{Ti}$ vs. $(\mathrm{Fe}+\mathrm{Mg}) / \mathrm{Ti}$ (Fig. $6 \mathrm{~A})$ where slope $=\mathrm{Xcpx} /(2 \cdot \mathrm{Xol}+\mathrm{Xcpx})$ for augite with $33 \%$ Wo or slope $=(1.2$ $\cdot \mathrm{Xcpx}) /(2 \cdot \mathrm{Xol}+0.9 \cdot \mathrm{Xcpx})$ for augite with $40 \% \mathrm{Wo}$. The 504B data yield a slope of $0.4874(R=0.863 ; \pm 95 \%=0.4302$ to 0.5447$)$, which gives olivine/(olivine + augite) of $0.345(0.295$ to 0.398$)$ for augite with $33 \%$ Wo and $0.439(0.3995$ to 0.486$)$ for augite with $40 \%$ Wo. Combined with the results from $\mathrm{F}^{\prime \prime \prime} / \mathrm{Ti}$ vs. $\mathrm{Al} / \mathrm{Ti}$ this yields olivine/ (olivine + augite + plagioclase) of 0.089 for augite with $33 \%$ Wo and 0.095 for augite with $40 \%$ Wo. It is interesting to note that the details of this plot are consistent with the CHAOS model in that the initial fractionation (from the upper right toward the middle of the plotted points) has a relatively shallow slope, indicating that it is dominated by olivine, while the final fractionation (from the middle of the plotted points toward the lower left) has a relatively steeper slope, indicating that it is dominated by augite. The calculations above using the slope of the best-fit line give the average fractionation trend.
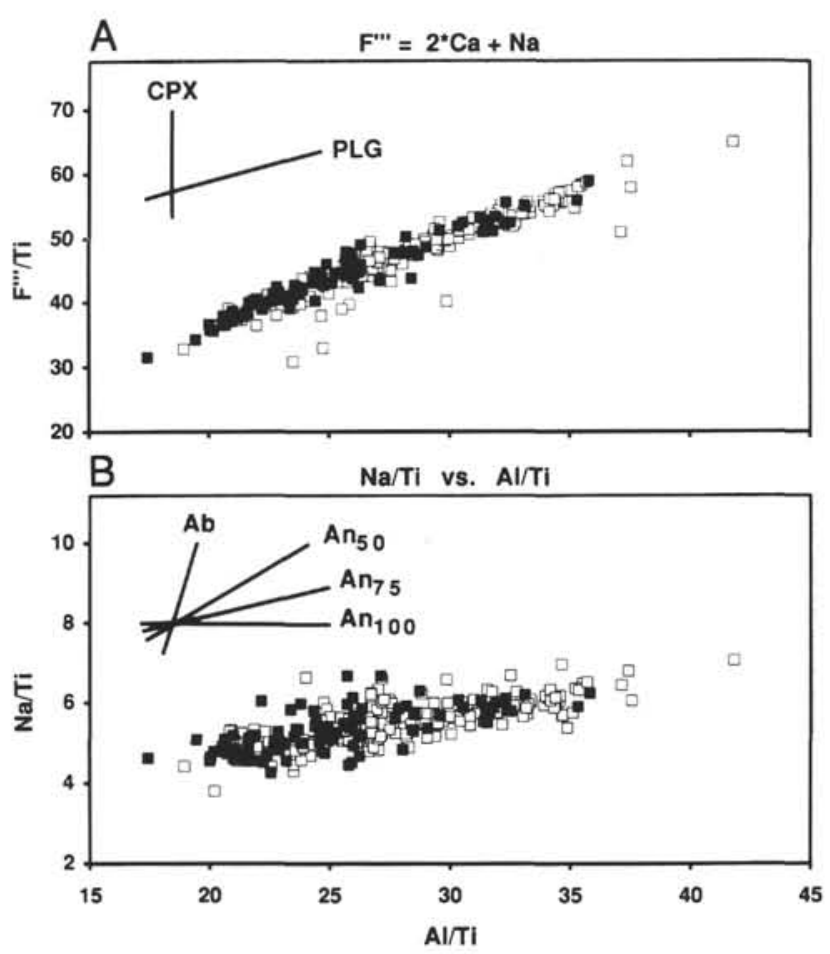

Figure 5. A. Pearce element ratio plot of 504B group D MORB samples. The fractionation of plagioclase (PLG) will result in a trend parallel to a slope of 1.0; fractionation of augite (CPX) will result in a trend parallel to a slope of $\infty$; fractionation of olivine or orthopyroxene will have no effect on this diagram as neither contains significant amounts of $\mathrm{Ca}, \mathrm{Na}$, or Al. Symbols as in Figure 1. B. Pearce element ratio plot of 504B group D MORB samples, The fractionation of albite $(\mathrm{Ab})$ will result in a trend parallel to a slope of 1.0; fractionation of anorthite $\left(\mathrm{An}_{100}\right)$ will result in a trend parallel to a slope of 0.0. Symbols as in Figure 1.

Because both olivine and augite have significant amounts of $\mathrm{Fe}$ and $\mathrm{Mg}$, the compositions of these solid solution series cannot be independently determined using Pearce element ratios. A plot of $\mathrm{Mg} / \mathrm{Ti}$ vs. $(\mathrm{Fe}+\mathrm{Mg}) / \mathrm{Ti}$ (Fig. $6 \mathrm{~B}$ ), however, yields an average $\mathrm{Mg \#}$ for olivine and augite (slope $=\mathrm{XMg} /[\mathrm{XMg}+\mathrm{XFe}]$ ). The 504B data yield a slope of $0.8046(R=0.992 ; \pm 95 \%=0.7830$ to 0.8261$)$, which gives an average $\mathrm{Mg} \#$ of 80.5 . Assuming $\mathrm{KD}^{\mathrm{Fe}} / \mathrm{Mg}$ ol $/ \mathrm{lq}=0.30$ (Roeder, 1974 ) and $\mathrm{KD}^{\mathrm{Fe}} / \mathrm{Mg} \mathrm{cpx} / \mathrm{lq}=0.23$ (Grove and Bence, 1977), and using the values for olivine/augite previously calculated, the distribution of $\mathrm{Mg}$ and $\mathrm{Fe}$ between augite and olivine can be calculated; the $\mathrm{Mg} \#$ for olivine $=78.0-78.8$ and the $\mathrm{Mg} \#$ for augite $=82.2-82.8$.

All of the mineral proportions calculated using Pearce element ratios are in cation \%. To compare with mineral proportions calculated by other computer models these have to be converted to wt $\%$ by multiplying by the molecular weight of each phase, dividing by the number of cations in the phase, and then renormalizing to $100 \%$. For samples in which the olivine and augite have high Mg\#s and the plagioclase has a high An\%, the conversion from cation \% to wt\% makes only a minor change in the mineral percentages. The Pearce element data for the 504B suite are summarized in Table 3. Four separate models are presented; Model 1 uses Figures 5A, 5B, 4B, and $6 \mathrm{~B}$ and assumes an augite of $\mathrm{Ca}_{0.67}\left[\mathrm{Fe}+\mathrm{Mg}_{1.33} \mathrm{Si}_{2} \mathrm{O}_{6}\right.$, Model 2 uses Figures $5 \mathrm{~A}, 5 \mathrm{~B}, 4 \mathrm{~B}$, and $6 \mathrm{~B}$ and assumes an augite of $\mathrm{Ca}_{0.80}[\mathrm{Fe}+$ $\mathrm{Mg}_{1.20} \mathrm{Si}_{2} \mathrm{O}_{6}$, Model 3 uses Figures $5 \mathrm{~A}, 5 \mathrm{~B}, 6 \mathrm{~A}$, and $6 \mathrm{~B}$ and assumes an augite of $\mathrm{Ca}_{0.67}\left[\mathrm{Fe}+\mathrm{Mg}_{1.33} \mathrm{Si}_{2} \mathrm{O}_{6}\right.$, and Model 4 uses Figures $5 \mathrm{~A}$, $5 \mathrm{~B}, 6 \mathrm{~A}$, and $6 \mathrm{~B}$ and assumes an augite of $\mathrm{Ca}_{0.80}\left[\mathrm{Fe}+\mathrm{Mg}_{1.20} \mathrm{Si}_{2} \mathrm{O}_{6}\right.$. The robustness of the method is illustrated by the fact that the four models yield similar results. 


\section{LEAST-SQUARES-FIT PARENT-DAUGHTER CALCULATIONS}

Least-squares-fit mixing models (Bryan et al., 1969; Wright and Doherty, 1970; Bryan, 1986) are standard fare for igneous petrology. In such models, the user inputs a parent magma composition, a daughter magma composition, and the compositions of fractionated mineral phases and/or assimilated xenoliths. In some versions of the program, the user can specify how each element is to be weighted in the model, so that elements that are known to be accurately determined and not affected by alteration can be more heavily weighted than elements less well determined or those suspected to have been affected by alteration. The program then does a multivariate least-squares fit to determine the best proportions of parent magma, fractionated minerals, and assimilated xenoliths that can be mixed to produce the daughter composition. There is no unique solution, so a successful least-squares-fit does not necessarily mean that the user has correctly modeled the differentiation that has occurred. On the other hand, not every mixture of parent, daughter, and fractionated or assimilated phases will yield a successful least-squares-fit (i.e., one in which the residuals for each element are within experimental error), and there is no control on whether a particular phase is added to or subtracted from the parent magma, so that in some cases where there is a successful fit mathematically, the mixing proportions suggest an unreasonable model (i.e., a model in which a fit is achieved by adding an unreasonably large amount of one phase compensated for by subtracting an unreasonably large amount of another phase). A disadvantage of this method is that the user needs to specify the compositions of the fractionated and assimilated phases. Electron microprobe data on phenocrysts, if available, usually provide a good starting point. If mineral composition data are not available, a trial and error approach must be used to determine the compositions of the phases that will best describe the process. An additional disadvantage of this model for a large data set is that only two compositions (one parent and one daughter) are modeled at a time. The program is best suited for situations in which the general scheme of differentiation is known (or suspected) and the user wishes to determine the relative proportions of the phases involved.

In this exercise a single parent with a high $\mathrm{Mg \#} \mathrm{(62.7)} \mathrm{and} \mathrm{a} \mathrm{single}$ daughter with a low Mg\# (53.2) were used (Table 4). Mineral compositions were taken from the phenocryst assemblage observed in Hole 504B samples (e.g., Natland et al., 1983; Kempton et al., 1985). This simple approach has resulted in a solution with low element residuals and petrologically reasonable mixing proportions. The removal of $5.0 \%$ olivine, $8.0 \%$ augite, and $14.8 \%$ plagioclase from a high $\mathrm{Mg \#}$ parent results in a low $\mathrm{Mg} \#$ daughter after $27.6 \%$ total crystallization. The cumulus assemblage in the complementary gabbro would be $18.1 \%$ olivine, $29.1 \%$ augite, and $53.8 \%$ plagioclase (Table 5).

\section{CORRELATION COEFFICIENT PATTERNS}

The processes affecting the evolution of a suite of cogenetic igneous rocks, be they magma mixing, multiphase fractionation, or wallrock assimilation, will result in predictable compositional relationships, if the processes and chemical data for all components are known. A unique way of looking at these relationships is to calculate the correlation coefficients between all analyzed elements. The resultant correlation coefficient matrix can then be compared, graphically, with similar matrices that have been calculated from various petrologic models. A simple, single-stage process such as fractionating olivine from a liquid, or mixing two magmas of constant composition, results in correlation coefficients that are either +1 , or -1 (or 0 , in the rare case where the abundance of an element is the same in both endmembers). Additional stages, or complexities, will reduce these correlations depending on the processes and compositions involved. Cox and Clifford (1982) describe this correlation method in detail, and have written a computer program named DARWIN to test various simple or complex evolutionary scenarios. They emphasize that this
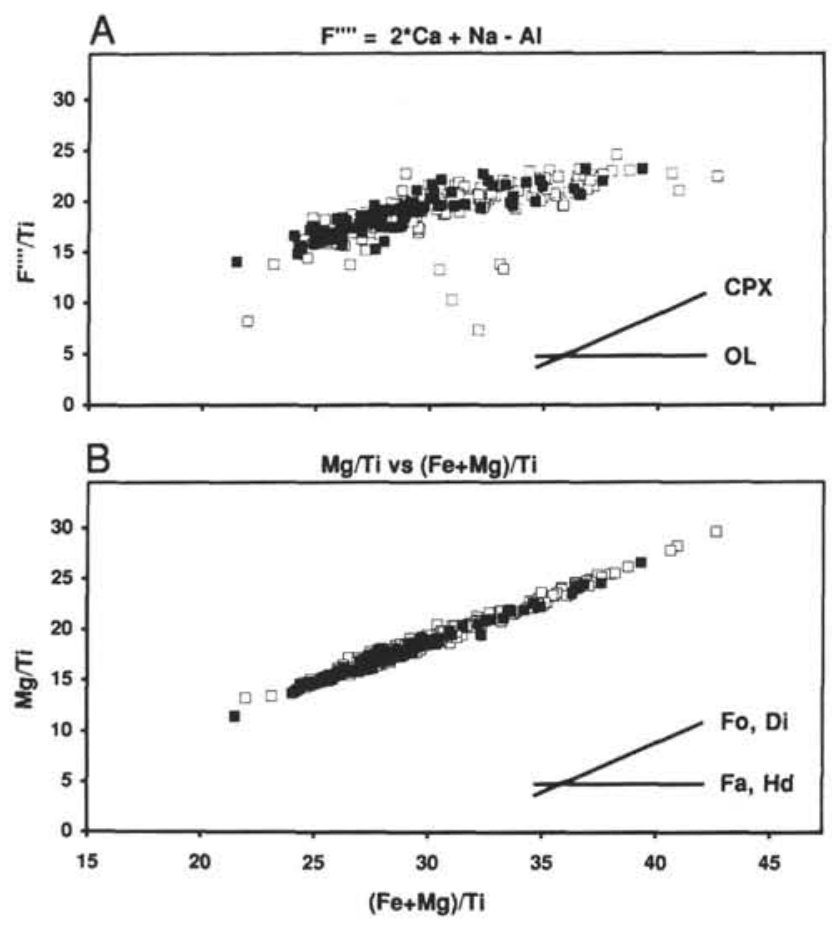

Figure 6. A. Pearce element ratio plot of 504B group D MORB samples. The fractionation of olivine $(\mathrm{OL})$ or orthopyroxene $(\mathrm{OPX})$ will result in a trend parallel to a slope of 0.0 ; fractionation of augite $(\mathrm{CPX})$ will result in a trend parallel to a slope of 1.0; fractionation of plagioclase will have no effect on this diagram. Symbols as in Figure 1. B. Pearce element ratio plot of 504B group D MORB samples. The fractionation of fayalite $(\mathrm{Fa})$, and/or hedenbergite $(\mathrm{Hd})$ will result in a trend parallel to a slope of 0.0 ; fractionation of forsterite (Fo) and/or diopside (Di) will result in a trend parallel to a slope of 1.0. Symbols as in Figure 1.

approach is meant to complement, not replace, other modeling tools. The striking advantage to this approach is its ability to easily examine the behavior of a large number of elements, providing greater detail to the selected model, or alerting the user to possible difficulties.

To use DARWIN, the compositions of an initial liquid and each modifying phase or component are first specified. Next, whether components are to be added or subtracted, and by what percentages, must be stipulated. The program then calculates a mean rock composition and the correlation coefficients between the initial composition and the new mean. With each successive stage of evolution (i.e., a new fractionating phase or added magma), DARWIN calculates a new mean rock composition and correlation patterns. These patterns are printed out graphically, allowing a large number of modeling options to be tested quickly. Cox and Clifford stress that it is not important to match the observed patterns exactly. Instead, the patterns are meant for qualitative comparisons, matching or excluding patterns from various models.

This method was tested with two data sets: (1) the 93 aphyric to sparsely phyric basalt and diabase samples described above, and (2) a series of synthetic compositions calculated by the computer program CHAOS (Nielsen, 1985; 1990) that cover the same range of $\mathrm{Mg \# s}$ as the natural suite. Correlation coefficients for both of these data sets (Table 6) were calculated for $\mathrm{SiO}_{2}, \mathrm{TiO}_{2}, \mathrm{Al}_{2} \mathrm{O}_{3}$, total iron as $\mathrm{Fe}_{2} \mathrm{O}_{3}\left(\mathrm{Fe}_{2} \mathrm{O}_{3} *\right), \mathrm{MnO}, \mathrm{MgO}, \mathrm{CaO}, \mathrm{Na}_{2} \mathrm{O}, \mathrm{Zr}, \mathrm{Y}, \mathrm{Sr}$, and $\mathrm{Ni}$, using a computer spreadsheet. DARWIN was set up to simulate a multistage fractionation of approximately $6 \%$ olivine, $20 \%$ plagioclase, and $11 \%$ clinopyroxene from an initial primitive liquid, and the resulting correlation matrix is presented in Table 6. Mineral proportions are similar to those calculated earlier by the least-squares-fit mixing program. 
Table 3. Results from Pearce element ratio analysis of 504B samples.

\begin{tabular}{|c|c|c|c|c|}
\hline Model & 1 & 2 & 3 & 4 \\
\hline Assumed augite (Wo\%) & 33 & 40 & 33 & 40 \\
\hline $\begin{array}{l}\text { Cation \% } \\
\text { Olivine/total crystals } \\
\text { Plagioclase/total crystals } \\
\text { Augite/total crystals }\end{array}$ & $\begin{array}{l}12.1 \\
61.8 \\
26.1\end{array}$ & $\begin{array}{l}13.0 \\
64.4 \\
22.7\end{array}$ & $\begin{array}{r}8.9 \\
64.1 \\
27.1\end{array}$ & $\begin{array}{r}9.5 \\
66.9 \\
23.6\end{array}$ \\
\hline $\begin{array}{l}\text { Weight } \% \\
\text { Olivine/total crystals } \\
\text { Plagioclase/total crystals } \\
\text { Augite/total crystals }\end{array}$ & $\begin{array}{l}11.4 \\
62.3 \\
26.3\end{array}$ & $\begin{array}{l}12.2 \\
65.0 \\
22.8\end{array}$ & $\begin{array}{r}8.3 \\
64.4 \\
27.2\end{array}$ & $\begin{array}{r}8.9 \\
67.4 \\
23.7\end{array}$ \\
\hline $\begin{array}{l}\text { Mineral compositions } \\
\text { Average olivine (Fo\%) } \\
\text { Average plagioclase (An\%) } \\
\text { Average augite } \mathrm{Mg} \#\end{array}$ & $\begin{array}{l}78.4 \\
82.5 \\
82.5\end{array}$ & $\begin{array}{l}78.8 \\
82.5 \\
82.8\end{array}$ & $\begin{array}{l}78.0 \\
82.5 \\
82.2\end{array}$ & $\begin{array}{l}78.4 \\
82.5 \\
82.5\end{array}$ \\
\hline
\end{tabular}

Table 4. Compositions used as input for DARWIN and least-squares-fit calculations.

\begin{tabular}{lrrrr}
\hline & Initial liquid & Olivine & Plagioclase & Augite \\
\hline $\mathrm{SiO}_{2}(\%)$ & 50.30 & 40.50 & 46.60 & 52.90 \\
$\mathrm{TiO}_{2}$ & 0.91 & 0.00 & 0.00 & 0.57 \\
$\mathrm{Al}_{2} \mathrm{O}_{3}$ & 15.31 & 0.00 & 33.46 & 2.40 \\
$\mathrm{FeO}$ & 9.50 & 12.20 & 0.18 & 5.60 \\
$\mathrm{MnO}$ & 0.18 & 0.16 & 0.00 & 0.15 \\
$\mathrm{MgO}$ & 8.95 & 46.39 & 0.25 & 16.80 \\
$\mathrm{CaO}$ & 13.01 & 0.34 & 17.76 & 21.30 \\
$\mathrm{Na}$ & 1.83 & 0.00 & 1.53 & 0.28 \\
$\mathrm{~K}_{2} \mathrm{O}$ & 0.01 & 0.00 & 0.00 & 0.00 \\
$\mathrm{P}_{2} \mathrm{O}_{5}$ & 0.06 & 0.00 & 0.00 & 0.00 \\
$\mathrm{Zr}(\mathrm{ppm})$ & 44 & 0 & 0 & 7 \\
$\mathrm{Y}$ & 25 & 0 & 0 & 13 \\
$\mathrm{Sr}$ & 55 & 0 & 99 & 11 \\
$\mathrm{Ni}$ & 107 & 930 & 0 & 150 \\
& & & & \\
\hline
\end{tabular}

Note: Total iron as FeO.

Table 5. Results of least-squares-fit calculations.

\begin{tabular}{lccr}
\hline & \multicolumn{2}{c}{ Evolved liquids } & \\
\cline { 2 - 3 } & Observed & Calculated & Residual \\
\hline $\mathrm{SiO}_{2}(\%)$ & 51.35 & 51.29 & -0.06 \\
$\mathrm{TiO}_{2}$ & 1.26 & 1.19 & -0.07 \\
$\mathrm{Al}_{2} \mathrm{O}_{3}$ & 13.98 & 14.01 & 0.03 \\
$\mathrm{FeO}$ & 11.39 & 11.62 & 0.23 \\
$\mathrm{MnO}$ & 0.21 & 0.22 & 0.01 \\
$\mathrm{MgO}$ & 7.25 & 7.24 & -0.01 \\
$\mathrm{CaO}$ & 11.85 & 11.94 & 0.09 \\
$\mathrm{Na}{ }_{2} \mathrm{O}$ & 2.25 & 2.18 & -0.07 \\
$\mathrm{~K}_{2} \mathrm{O}$ & 0.01 & 0.01 & 0.00 \\
$\mathrm{P}_{2} \mathrm{O}_{5}$ & 0.08 & 0.08 & 0.00 \\
& & $\Sigma \mathrm{r} 2=$ & 0.08 \\
& & & \\
& & Percentages & \\
Initial liquid & 1.381 & 100.00 & \\
Olivine & -0.069 & -5.00 & \\
Plagioclase & -0.205 & -14.84 & \\
Augite & -0.111 & -8.04 & \\
Evolved liquid & 0.996 & 72.12 & \\
\hline
\end{tabular}

Note: Total iron as FeO.

The compositions of the fractionated phases (Table 4) are in reasonable agreement with analyses from Hole 504B (e.g., Natland et al., 1983; Kempton et al., 1985) and 1-atm equilibrium compositions (e.g., Roeder and Emslie, 1970; Drake, 1976) calculated by the program CHAOS.

In the 504B data set, $\mathrm{TiO}_{2}$ exhibits moderate to strongly positive correlations $(+0.5$ to +0.9$)$ with $\mathrm{SiO}_{2}, \mathrm{Fe}_{2} \mathrm{O}_{3}{ }^{*}, \mathrm{MnO}, \mathrm{Na}_{2} \mathrm{O}, \mathrm{Zr}$, and $\mathrm{Y}$; strongly negative correlations $(-0.7$ to -0.8$)$ with $\mathrm{A}_{2} \mathrm{O}_{3}, \mathrm{MgO}, \mathrm{CaO}$,
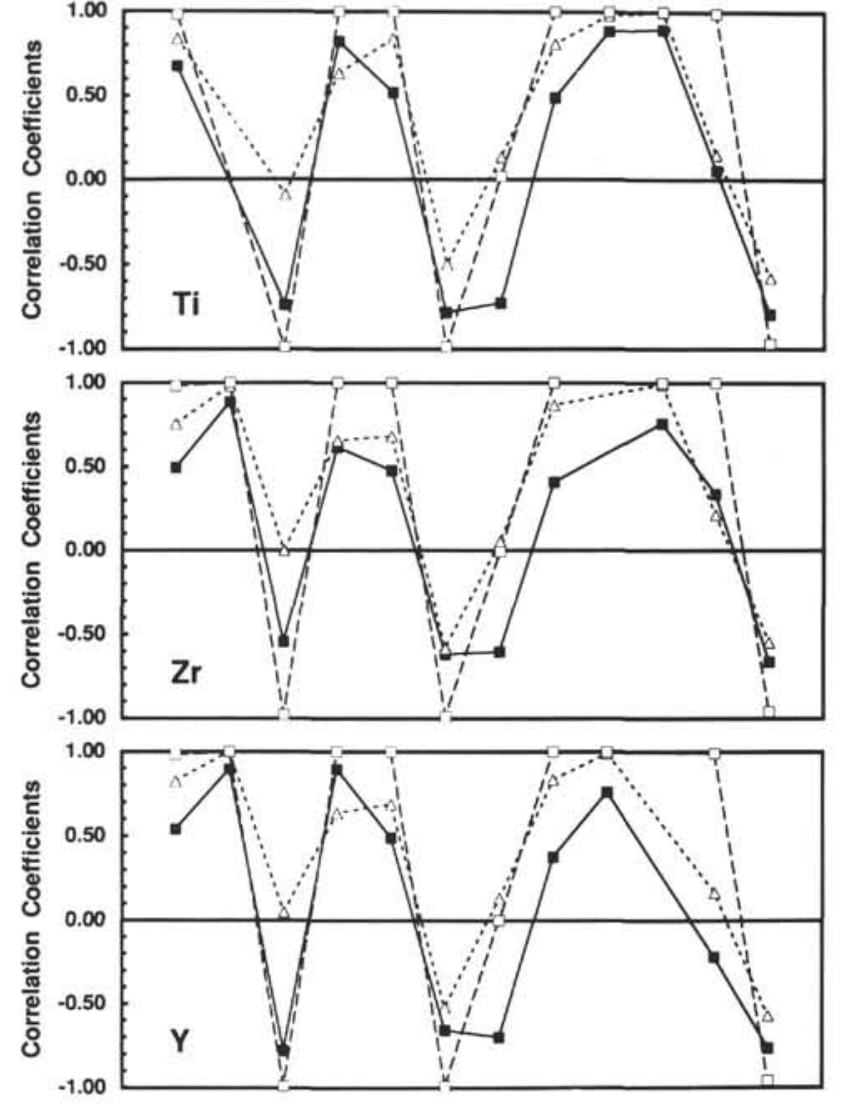

$\begin{array}{llllllllllll}\mathrm{Si} & \mathrm{Ti} & \mathrm{Al} & \mathrm{Fe} & \mathrm{Mn} & \mathrm{Mg} & \mathrm{Ca} & \mathrm{Na} & \mathrm{Zr} & \mathrm{Y} & \mathrm{Sr} & \mathrm{NI}\end{array}$

Figure 7. Correlation coefficient patterns for $\mathrm{Ti}, \mathrm{Zr}$, and $\mathrm{Y}$. Symbols: filled boxes and solid lines $=$ Hole 504B suite; open triangles and dotted lines $=$ output from DARWIN; open boxes and dashed lines = output from CHAOS.

and $\mathrm{Ni}$; and low correlations $(+0.1)$ with $\mathrm{Sr}$. The patterns produced by subtracting olivine, plagioclase, and clinopyroxene via DARWIN display the same general pattern as the selected 504B samples (Fig. 7), with the exception of $\mathrm{Al}_{2} \mathrm{O}_{3}$ and $\mathrm{CaO}$, which show almost no correlation $(-0.1,+0.1)$. The pattern resulting from the liquids calculated by $\mathrm{CHAOS}$ corresponds well with $\mathrm{SiO}_{2}, \mathrm{Al}_{2} \mathrm{O}_{3}, \mathrm{Fe}_{2} \mathrm{O}_{3}$ *, $\mathrm{MnO}$, $\mathrm{MgO}, \mathrm{Na}_{2} \mathrm{O}, \mathrm{Zr}$, Y, and $\mathrm{Ni}$, but misses $\mathrm{CaO}(0.0)$ and $\mathrm{Sr}(+1.0)$. Yttrium and $\mathrm{Zr}$ correlation patterns for both natural and calculated compositions are comparable to those of $\mathrm{TiO}_{2}$.

The patterns for compatible elements $\mathrm{Al}_{2} \mathrm{O}_{3}, \mathrm{MgO}$, and $\mathrm{CaO}$ (Fig. 8 ) are much less coherent. In the 504B data set, $\mathrm{MgO}$ is positively correlated with $\mathrm{Al}_{2} \mathrm{O}_{3}, \mathrm{CaO}$, and $\mathrm{Ni}(+0.5$ to +0.7$)$, and negatively correlated with $\mathrm{SiO}_{2}, \mathrm{TiO}_{2}, \mathrm{Fe}_{2} \mathrm{O}_{3}{ }^{*}, \mathrm{Na}_{2} \mathrm{O}, \mathrm{Zr}$, Y ( -0.5 to -0.8$) ; \mathrm{MnO}$ and $\mathrm{Sr}$ show almost no correlation with $\mathrm{MgO}$. The $\mathrm{MgO}$ correlation values from DARWIN are in reasonable agreement with the more incompatible elements $\mathrm{TiO}_{2}, \mathrm{Zr}$, Y, and compatibles $\mathrm{SiO}_{2}, \mathrm{Na}_{2} \mathrm{O}$, and $\mathrm{Ni}$, but the values for $\mathrm{Al}_{2} \mathrm{O}_{3}, \mathrm{Fe}_{2} \mathrm{O}_{3}{ }^{*}$, and $\mathrm{CaO}$ are correlated in the opposite sense. The CHAOS pattern, on the other hand, is a slightly better match. It is roughly the same as the observed 504B pattern, except for $\mathrm{Sr}$, which is strongly correlated $(-0.97)$ in the calculated compositions, but not in the rocks $(-0.1)$. The pattern matching for $\mathrm{Al}_{2} \mathrm{O}_{3}$ and $\mathrm{CaO}$ ranges from poor to nonexistent, respectively. $\mathrm{CHAOS}$ matches the $\mathrm{Al}_{2} \mathrm{O}_{3}$ pattern slightly better than DARWIN does, but neither program effectively mimics the observed $\mathrm{CaO}$ correlation pattern in the 504B data set.

Changing the proportions of olivine, plagioclase, and clinopyroxene does not drastically affect these patterns, if the proportions are 
Table 6. Correlation coefficient matrices from natural and calculated compositions.

\begin{tabular}{|c|c|c|c|c|c|c|c|c|c|c|c|}
\hline \multicolumn{12}{|c|}{ Correlation coefficient matrix $-504 \mathrm{~B}$ basalts and diabases } \\
\hline & $\mathrm{SiO}_{2}$ & $\mathrm{TiO}_{2}$ & $\mathrm{Al}_{2} \mathrm{O}_{3}$ & $\mathrm{Fe}_{2} \mathrm{O}_{3}$ & $\mathrm{MnO}$ & $\mathrm{MgO}$ & $\mathrm{CaO}$ & $\mathrm{Na}_{2} \mathrm{O}$ & $\mathrm{Zr}$ & $\mathrm{Y}$ & $\mathrm{Sr}$ \\
\hline $\begin{array}{l}\mathrm{TiO}_{2} \\
\mathrm{Al}_{2} \mathrm{O}_{3} \\
\mathrm{Fe}_{2} \mathrm{O}_{3} \\
\mathrm{MnO} \\
\mathrm{MgO} \\
\mathrm{CaO} \\
\mathrm{Na}_{2} \mathrm{O} \\
\mathrm{Zr} \\
\mathrm{Y} \\
\mathrm{Sr} \\
\mathrm{Ni}\end{array}$ & $\begin{array}{r}0.67 \\
-0.66 \\
0.55 \\
0.19 \\
-0.67 \\
-0.58 \\
0.26 \\
0.49 \\
0.54 \\
-0.04 \\
-0.72\end{array}$ & $\begin{array}{r}-0.74 \\
0.82 \\
0.52 \\
-0.78 \\
-0.73 \\
0.49 \\
0.89 \\
0.89 \\
0.05 \\
-0.80\end{array}$ & $\begin{array}{r}-0.87 \\
-0.56 \\
0.48 \\
0.51 \\
-0.22 \\
-0.55 \\
-0.78 \\
0.36 \\
0.79\end{array}$ & $\begin{array}{r}0.54 \\
-0.64 \\
-0.68 \\
0.29 \\
0.62 \\
0.89 \\
-0.36 \\
-0.76\end{array}$ & $\begin{array}{r}-0.14 \\
-0.21 \\
0.12 \\
0.48 \\
0.49 \\
-0.19 \\
-0.41\end{array}$ & $\begin{array}{r}0.65 \\
-0.51 \\
-0.62 \\
-0.66 \\
-0.07 \\
0.72\end{array}$ & $\begin{array}{r}-0.48 \\
-0.60 \\
-0.70 \\
-0.07 \\
0.58\end{array}$ & $\begin{array}{r}0.41 \\
0.38 \\
0.29 \\
-0.49\end{array}$ & $\begin{array}{r}0.76 \\
0.34 \\
-0.66\end{array}$ & $\begin{array}{l}-0.22 \\
-0.77\end{array}$ & 0.10 \\
\hline \multicolumn{12}{|c|}{ Correlation coefficient matrix-DARWIN } \\
\hline & $\mathrm{SiO}_{2}$ & $\mathrm{TiO}_{2}$ & $\mathrm{Al}_{2} \mathrm{O}_{3}$ & $\mathrm{Fe}_{2} \mathrm{O}_{3}$ & $\mathrm{MnO}$ & $\mathrm{MgO}$ & $\mathrm{CaO}$ & $\mathrm{Na}_{2} \mathrm{O}$ & $\mathrm{Zr}$ & $\mathrm{Y}$ & $\mathrm{Sr}$ \\
\hline $\begin{array}{l}\mathrm{TiO}_{2} \\
\mathrm{Al}_{2} \mathrm{O}_{3} \\
\mathrm{Fe}_{2} \mathrm{O}_{3} \\
\mathrm{MnO} \\
\mathrm{MgO} \\
\mathrm{CaO} \\
\mathrm{Na}_{2} \mathrm{O} \\
\mathrm{Zr} \\
\mathrm{Y} \\
\mathrm{Sr} \\
\mathrm{Ni}\end{array}$ & $\begin{array}{r}0.84 \\
0.18 \\
0.15 \\
0.48 \\
-0.77 \\
0.65 \\
0.74 \\
0.76 \\
0.82 \\
0.36 \\
-0.86\end{array}$ & $\begin{array}{r}-0.09 \\
0.63 \\
0.84 \\
-0.50 \\
0.13 \\
0.81 \\
0.98 \\
1.00 \\
0.15 \\
-0.58\end{array}$ & $\begin{array}{r}-0.68 \\
-0.58 \\
-0.77 \\
0.59 \\
0.49 \\
0.00 \\
0.05 \\
0.98 \\
-0.67\end{array}$ & $\begin{array}{r}0.94 \\
0.32 \\
-0.65 \\
0.24 \\
0.66 \\
0.64 \\
-0.52 \\
0.27\end{array}$ & $\begin{array}{r}0.05 \\
-0.34 \\
0.43 \\
0.68 \\
0.69 \\
-0.55 \\
0.19\end{array}$ & $\begin{array}{r}-0.79 \\
-0.82 \\
-0.58 \\
-0.52 \\
-0.87 \\
0.99\end{array}$ & $\begin{array}{r}0.32 \\
0.05 \\
0.13 \\
0.61 \\
-0.83\end{array}$ & $\begin{array}{r}0.87 \\
0.83 \\
0.67 \\
-0.81\end{array}$ & $\begin{array}{r}0.99 \\
0.21 \\
-0.55\end{array}$ & $\begin{array}{r}0.17 \\
-0.57\end{array}$ & -0.79 \\
\hline \multicolumn{12}{|c|}{ Correlation coefficient matrix - CHAOS } \\
\hline & $\mathrm{SiO}_{2}$ & $\mathrm{TiO}_{2}$ & $\mathrm{Al}_{2} \mathrm{O}_{3}$ & $\mathrm{Fe}_{2} \mathrm{O}_{3}$ & $\mathrm{MnO}$ & $\mathrm{MgO}$ & $\mathrm{CaO}$ & $\mathrm{Na}_{2} \mathrm{O}$ & $\mathrm{Zr}$ & $\mathrm{Y}$ & $\mathrm{Sr}$ \\
\hline $\begin{array}{l}\mathrm{TiO}_{2} \\
\mathrm{Al}_{2} \mathrm{O}_{3} \\
\mathrm{Fe}_{2} \mathrm{O}_{3} \\
\mathrm{MnO} \\
\mathrm{MgO} \\
\mathrm{CaO} \\
\mathrm{Na}{ }_{2} \mathrm{O} \\
\mathrm{Zr} \\
\mathrm{Y} \\
\mathrm{Sr} \\
\mathrm{Ni}\end{array}$ & $\begin{array}{r}0.98 \\
-1.00 \\
0.97 \\
0.99 \\
-1.00 \\
0.20 \\
0.97 \\
0.98 \\
0.98 \\
0.95 \\
-0.99\end{array}$ & $\begin{array}{r}-0.99 \\
1.00 \\
1.00 \\
-0.99 \\
0.02 \\
1.00 \\
1.00 \\
1.00 \\
0.99 \\
-0.97\end{array}$ & $\begin{array}{r}-0.98 \\
-0.99 \\
1.00 \\
-0.16 \\
-0.98 \\
-0.98 \\
-0.99 \\
-0.97 \\
0.99\end{array}$ & $\begin{array}{r}1.00 \\
-0.98 \\
-0.04 \\
1.00 \\
1.00 \\
1.00 \\
1.00 \\
-0.95\end{array}$ & $\begin{array}{r}-0.99 \\
0.04 \\
1.00 \\
1.00 \\
1.00 \\
0.99 \\
-0.97\end{array}$ & $\begin{array}{r}-0.13 \\
-0.99 \\
-0.99 \\
-0.99 \\
-0.97 \\
0.98\end{array}$ & $\begin{array}{r}-0.03 \\
-0.01 \\
0.00 \\
-0.10 \\
-0.25\end{array}$ & $\begin{array}{r}1.00 \\
1.00 \\
1.00 \\
-0.95\end{array}$ & $\begin{array}{r}1.00 \\
1.00 \\
-0.96\end{array}$ & $\begin{array}{r}0.99 \\
-0.96\end{array}$ & -0.93 \\
\hline
\end{tabular}

varied within reasonable limits. The simulated patterns could be made to more closely approach those of the natural samples if steps were taken to fine tune the model by adding different liquid compositions to simulate the effect of variable primary liquid compositions, adding evolved liquids to simulate a periodically refilled magma chamber, or adding small amounts of some of the alteration minerals. It is not clear, however, that such fine tuning would add any new geologic insights to the model.

The application of the correlation method to the 504B data suggests several points to consider when using this approach. Correlation coefficients between moderate to highly incompatible elements (Ti, K, P, $\mathrm{Nb}, \mathrm{Zr}, \mathrm{Y}, \mathrm{Rb}, \mathrm{Ba}, \mathrm{La}, \mathrm{Ce}$, etc.) are easier to match than those for some of the compatible elements ( $\mathrm{Al}, \mathrm{Mg}$, and $\mathrm{Ca}) . \mathrm{SiO}_{2}, \mathrm{Fe}_{2} \mathrm{O}_{3}$, and $\mathrm{Ni}$, on the other hand, commonly agree with the fractionation model. This observation is in agreement with the results of Cox and Clifford (1982) for their East Iceland, Mahabaleshwar, and Rooi Rand suites. Although incompatible elements are preferred for this kind of modeling, the unusually low concentrations of many incompatible elements in Hole 504B samples ( $\mathrm{Nb} \leq 1.5 \mathrm{ppm} ; \mathrm{Rb}<0.4 \mathrm{ppm} ; \mathrm{Ba}<2 \mathrm{ppm} ; \mathrm{K}<200$ ppm; $\mathrm{P}_{2} \mathrm{O}_{5}<0.13 \%$ ), limits their usefulness for this exercise. In addition, $\mathrm{K}$, $\mathrm{Rb}$, and possibly $\mathrm{Sr}$ and $\mathrm{Na}$ have been affected by hydrothermal alteration (e.g., Alt et al., 1986). Another difficulty to consider is the relative homogeneity of the Hole 504B samples (Table 1). Suites of rocks that show little variation tend to have lower correlation coefficients and are more likely to be affected by outlying values for both the observed rocks and phase compositions (Cox and Clifford, 1982). In such cases, analytical error plays an important role because correlation coefficients become highly variable and difficult to match with seemingly small variations in composition.
Despite these difficulties, however, useful information has come out of this exercise. If only the relatively incompatible elements plus $\mathrm{SiO}_{2}$ and $\mathrm{Fe}_{2} \mathrm{O}_{3}{ }^{*}$ are considered, the patterns are consistent with a model of olivine, plagioclase, and clinopyroxene fractionation to explain the compositional variations in the 504B suite.

\section{CONCLUSIONS}

Four computer models have been used to examine the compositional variation in the 504B samples. The first two models, a liquidline-of-descent calculation (CHAOS) and Pearce element ratio analysis, require few input assumptions, and can be used to identify: (1) what phases are fractionating, (2) the compositions of those phases, and (3) the relative proportions of those phases. The other two models, least-squares-fit parent-daughter calculations and correlation coefficient patterns analysis (DARWIN), require a considerable amount of input assumptions, and are primarily useful for testing models (the least-squares-fit parent-daughter calculations do, however, yield the relative proportions of fractionating phases). All four computer models are consistent with a differentiation scheme for 504B magmas in which an initial high $\mathrm{Mg \#}$ parent fractionates plagioclase, augite, and olivine to produce a series of daughter magmas with lower Mg\#s. None of the models require significant amounts of assimilation or more than one parent magma composition to explain the variation observed in the 504B data.

If it is assumed that fractionation occurred in a crustal level magma chamber, the average composition of the residual gabbro can be calculated. The primary unknown in such a calculation is the amount of trapped liquid. Model gabbros have been calculated assuming $0 \%$, 
Table 7. Calculated average gabbros for Hole 504B.

\begin{tabular}{|c|c|c|c|c|c|c|c|c|c|c|c|c|}
\hline \multirow{5}{*}{$\begin{array}{l}\text { \% pore magma } \\
\% \text { olivine } \\
\% \text { plagioclase } \\
\% \text { augite }\end{array}$} & \multicolumn{3}{|c|}{ CHAOS models } & \multirow[b]{2}{*}{45.00} & \multicolumn{3}{|c|}{ Pearce element ratio models } & \multicolumn{5}{|c|}{ Least-squares-fit models } \\
\hline & 0.00 & 15.00 & 30.00 & & 0.00 & 15.00 & 30.00 & 45.00 & 0.00 & 15.00 & 30.00 & 45.00 \\
\hline & 19.10 & 16.24 & 13.37 & 10.51 & 10.20 & 8.67 & 7.14 & 5.61 & 17.92 & 15.23 & 12.54 & 9.86 \\
\hline & 57.50 & 48.88 & 40.25 & 31.63 & 64.80 & 55.08 & 45.36 & 35.64 & 28.83 & 24.51 & 20.18 & 15.86 \\
\hline & 23.40 & 19.89 & 16.38 & 12.87 & 25.00 & 21.25 & 17.50 & 13.75 & 53.25 & 45.26 & 37.28 & 29.29 \\
\hline $\mathrm{SiO}_{2}$ & 48.60 & 48.84 & 49.08 & 49.32 & 47.94 & 48.28 & 48.62 & 48.96 & 47.32 & 47.75 & 48.19 & 48.62 \\
\hline $\mathrm{TiO}_{2}^{2}$ & 0.13 & 0.26 & 0.38 & 0.51 & 0.13 & 0.26 & 0.38 & 0.50 & 0.16 & 0.28 & 0.40 & 0.52 \\
\hline $\mathrm{Al}_{2} \mathrm{O}_{3}$ & 19.16 & 18.56 & 17.96 & 17.36 & 22.44 & 21.35 & 20.25 & 19.16 & 18.51 & 18.01 & 17.50 & 17.00 \\
\hline $\mathrm{FeO}$ & 4.07 & 5.03 & 5.98 & 6.94 & 3.70 & 4.71 & 5.72 & 6.74 & 3.90 & 4.88 & 5.86 & 6.85 \\
\hline $\mathrm{MnO}$ & 0.09 & 0.11 & 0.12 & 0.13 & 0.06 & 0.08 & 0.10 & 0.12 & 0.07 & 0.09 & 0.10 & 0.12 \\
\hline $\mathrm{MgO}$ & 12.71 & 12.07 & 11.42 & 10.78 & 8.54 & 8.52 & 8.50 & 8.48 & 13.29 & 12.56 & 11.83 & 11.10 \\
\hline $\mathrm{CaO}$ & 13.55 & 13.43 & 13.31 & 13.20 & 15.84 & 15.38 & 14.91 & 14.45 & 15.66 & 15.22 & 14.79 & 14.35 \\
\hline $\mathrm{Na}_{2} \mathrm{O}$ & 1.71 & 1.75 & 1.79 & 1.82 & 1.33 & 1.42 & 1.52 & 1.61 & 0.90 & 1.06 & 1.21 & 1.37 \\
\hline $\mathrm{K}_{2} \mathrm{O}$ & 0.00 & 0.01 & 0.01 & 0.01 & 0.01 & 0.01 & 0.01 & 0.02 & 0.00 & 0.00 & 0.01 & 0.01 \\
\hline $\mathrm{P}_{2} \mathrm{O}_{5}$ & 0.00 & 0.01 & 0.02 & 0.03 & 0.00 & 0.01 & 0.02 & 0.03 & 0.00 & 0.01 & 0.02 & 0.03 \\
\hline Total & 100.03 & 100.05 & 100.07 & 100.10 & 99.98 & 100.01 & 100.04 & 100.07 & 99.81 & 99.86 & 99.92 & 99.98 \\
\hline
\end{tabular}
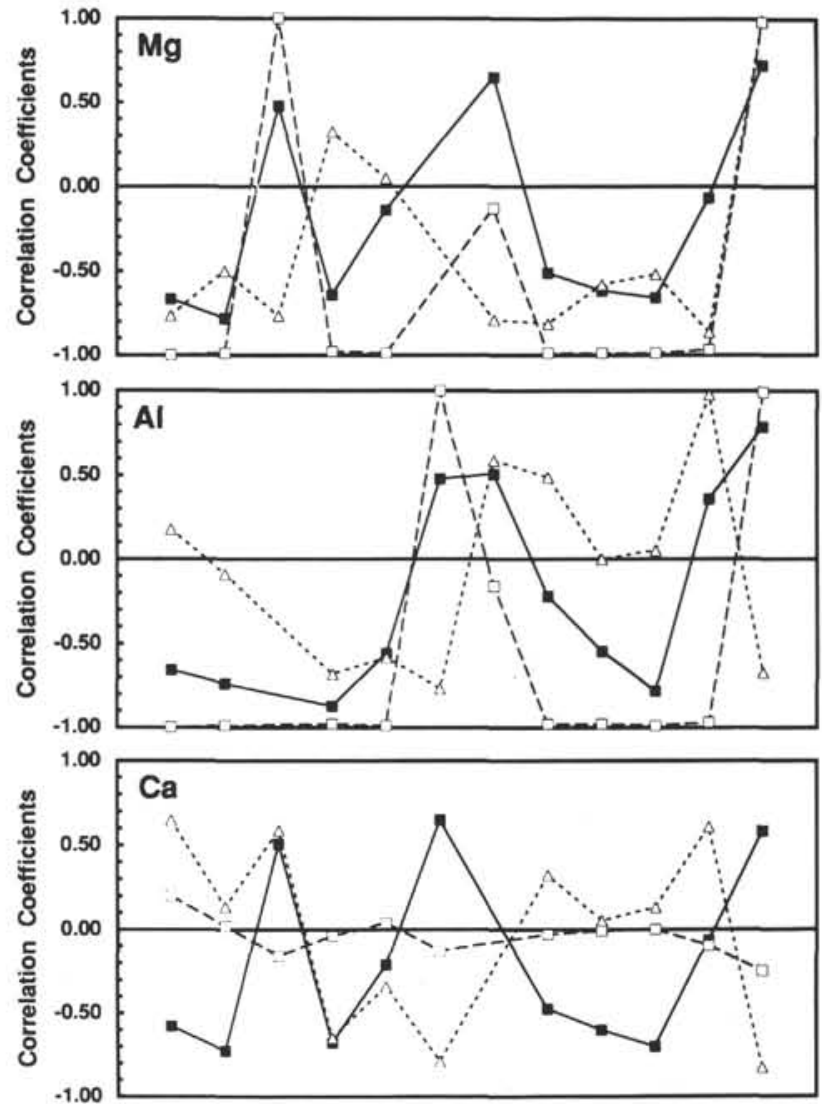

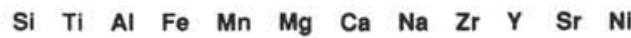

Figure 8. Correlation coefficient patterns for $\mathrm{Mg}, \mathrm{Al}$, and $\mathrm{Ca}$. Symbols as in Figure 7.

$15 \%, 30 \%$, and $45 \%$ trapped liquid of average 504B composition using the cumulus mineral proportions calculated by: (1) liquid-lineof-descent calculations, (2) Pearce element ratio analysis, and (3) least-squares-fit parent-daughter calculations (Table 7). Given that the most primitive magmas (aphyric, unaltered whole-rock compositions) from Hole 504B are approximately $\mathrm{Mg} \#=68$, and that the average magma is approximately $\mathrm{Mg} \#=60.5$, we can calculate that the average aphyric rock in the section has fractionated approximately $25 \%\left(\mathrm{TiO}_{2}\right.$ $=0.72 \%$ at $\mathrm{Mg} \#=68$ and $0.99 \%$ at $\mathrm{Mg} \#=60.5$, fractionation $=27.6 \%$; $\mathrm{Y}=19 \mathrm{ppm}$ at $\mathrm{Mg} \#=68$ and $25 \mathrm{ppm}$ at $\mathrm{Mg} \#=60.5$, fractionation $=$
$23.1 \% ; \mathrm{Zr}=38 \mathrm{ppm}$ at $\mathrm{Mg \#}=68$ and $50 \mathrm{ppm}$ at $\mathrm{Mg} \#=60.5$, fractionation $=24.1 \%$ ). Fraction of the observed $1726 \mathrm{~m}$ of basalt and diabase would require a minimum thickness of $573 \mathrm{~m}$ of gabbro at Site 504B if we assume 0\% trapped liquid, or $1042 \mathrm{~m}$ of gabbro if we assume $45 \%$ trapped liquid.

The calculated residual gabbro derived from these calculations only represents the material necessary to account for the observed differentiation in the basalts and sheeted dikes in the upper $2 \mathrm{~km}$ of Hole 504B. The lower crustal section at Hole 504B is also likely to contain magmas that were injected into the crust and solidified in place, and some of these magmas may be more primitive than those observed in the upper part of the section. It is also possible that phenocryst-rich or xenocryst-rich magmas were intruded into the crust and contributed transported crystals to the lower crustal gabbros. The calculated gabbros, therefore, probably represent a minimum estimate; the lower crustal section at Hole 504B is probably thicker and more primitive than that calculated.

\section{ACKNOWLEDGMENTS}

This study has been supported in part by post-cruise support from USSAC. Anne Hull assisted with the drafting, and David Tuttle assisted with the photography. The manuscript was improved by helpful comments from Drs. W.B. Bryan, D.J. Geist, and H.B. Dick, and editorial assistance from N. McQuistion.

\section{REFERENCES $*$}

Alt, J.C., Honnorez, J., Laverne, C., and Emmermann, R., 1986. Hydrothermal alteration of a $1 \mathrm{~km}$ section through the upper oceanic crust, Deep Sea Drilling Project Hole 504B: mineralogy, chemistry, and evolution of seawater-basalt interactions. J. Geophys. Res., 91:10309-10335.

Autio, L.K., and Rhodes, J.M., 1983. Costa Rica Rift Zone basalts: geochemical and experimental data from a possible example of multistage melting. In Cann, J.R., Langseth, M.G., Honnorez, J., Von Herzen, R.P., White, S.M., et al., Init. Repts. DSDP, 69: Washington (U.S. Govt. Printing Office), 729-745.

Autio, L.K., Sparks, J.W., and Rhodes, J.M., 1989. Geochemistry of Leg 111 basalts: intrusive feeders for highly depleted pillows and flows. In Becker, K., Sakai, H., et al., Proc. ODP, Sci. Results, 111: College Station, TX (Ocean Drilling Program), 3-16.

Bryan, W.B., 1986. Linked evolutionary data arrays: a logical structure for petrologic modeling of multisource, multiprocess magmatic systems. $J$. Geophys. Res., 91:5891-5900.

Bryan, W.B., Finger, L.W., and Chayes, F., 1969. Estimating proportions in petrographic mixing equations by least-squares approximation. Science, 163:926-927.

\footnotetext{
Abbreviations for names of organizations and publications in ODP reference lists follow the style given in Chemical Abstracts Service Source Index (published by American Chemical Society).
} 
Cox, K.G., and Clifford, P., 1982. Correlation coefficient patterns and their interpretation in three basaltic suites. Contrib. Mineral. Petrol., 79:268-278.

Drake, M.J., 1976. Plagioclase-melt equilibria. Geochim. Cosmochim. Acta, 40:457-465.

Fisk, M.R., Nielsen, R.L., Harvey, P.K., Pezard, P., and Laverne, C., 1992. Magma chamber size, mantle recharge, and eruption at Site 504B, Costa Rica Rift. Eos, 73:496.

Grove, T.L., and Bence, A.E., 1977. Experimental study of pyroxene-liquidinteraction in quartz normative basalt 15597. Proc. Lunar Sci. Conf., 8:1549-1579.

Kempton, P.D., Autio, L.K., Rhodes, J.M., Holdaway, M.J., Dungan, M.A., and Johnson, P., 1985. Petrology of basalts from Hole 504B, Deep Sea Drilling Project, Leg 83. In Anderson, R.N., Honnorez, J., Becker, K., et al., Init. Repts. DSDP, 83: Washington (U.S. Govt. Printing Office), 129-164.

Natland, J.H., Adamson, A.C., Laverne, C., Melson, W.G., and O'Hearn, T. 1983. A compositionally nearly steady-state magma chamber at the Costa Rica Rift: evidence from basalt glass and mineral data, Deep Sea Drilling Project Sites 501, 504, and 505. In Cann, J.R., Langseth, M.G., Honnorez, J., Von Herzen, R.P., White, S.M., et al., Init. Repts. DSDP, 69: Washington (U.S. Govt. Printing Office), 811-858.

Nicholls, J., and Russell, J.K., 1990. Pearce element ratios: an overview, example, and bibliography. In Russell, J.K., and Stanley, C.R. (Eds.), Theory and Application of Pearce Element Ratios to Geochemical Data Analysis. Short Course Notes, Geol. Assoc. Canada, 8:11-21.

Nielsen, R.L., 1985. EQUIL.FOR: a program for the modeling of low-pressure differentiation processes in natural mafic magma bodies. Comput. Geosci., 11:531-546.

1990. Simulation of igneous differentiation processes. In Nicholls J., and Russell, J.K. (Eds.), Modern Methods of Igneous Petrology: Understanding Magmatic Processes. Mineral. Soc. Am., Rev. Mineral., 24:65-105.

Pearce, T.H., 1968. A contribution to the theory of variation diagrams. Contrib. Mineral. Petrol., 19:142-157.

1990. Getting the most from your analytical data: applications of Pearce element ratio analysis. In Russell, J.K., and Stanley, C.R. (Eds.), Theory and Application of Pearce Element Ratios to Geochemical Dato Analysis. Short Course Notes, Geol. Assoc. Canada, 99-130.

Roeder, P.L., 1974. Activity of iron and olivine solubility in basaltic liquids. Earth Planet. Sci. Lett., 23:397-410.

Roeder, P.L., and Emslie, R.F., 1970. Olivine-liquid equilibrium. Contrib, Mineral. Petrol., 29:275-289.

Shipboard Scientific Party, 1992. Site 504. In Dick, H.J.B., Erzinger, J., Stokking, L.B., et al., Proc. ODP, Init. Repts., 140: College Station, TX (Ocean Drilling Program), 37-200.
Wright, T.L., and Doherty, P.C., 1970. A linear programming and least squares computer method for solving petrologic mixing problems. Geol. Soc. Am. Bull., 81:1995-2008.

\section{Date of initial receipt: 11 May 1993 \\ Date of acceptance: 18 April 1994 \\ Ms 137/140SR-008}

\section{APPENDIX}

The slope on a Pearce element ratio diagram is equal to the change in the $\mathrm{Y}$-axis numerator divided by the change in the $\mathrm{X}$-axis numerator. Because these values are in cation percent, the effect of the addition or removal of the various possible fractionated minerals can be easily evaluated. In Figure $5 \mathrm{~B}, \mathrm{Na} / \mathrm{Ti}$ vs. $\mathrm{Al} / \mathrm{Ti}$, the slope is equal to $\Delta \mathrm{Na} / \Delta \mathrm{Al}$. Because plagioclase is the only phase with significant amounts of $\mathrm{Na}$ or $\mathrm{Al}$, the change in $\mathrm{Na}$ is equal to the fraction of albite (Xab) in the crystallization assemblage, and the change in $\mathrm{Al}$ is equal to the fraction of albite (Xab) plus twice the fraction of anorthite ( 2 - Xan). Therefore: Xab slope $=\mathrm{Xab} /[\mathrm{Xab}+(2 \cdot \mathrm{Xan})]=\mathrm{Xab} /[\mathrm{Xab}+(2 \cdot(1-\mathrm{Xab}))]=\mathrm{Xab} /[2-$

$\mathrm{Xab}=(2 \cdot$ slope $) /(1+$ slope $)$

If more than one mineral phase is involved, the number of cations in each phase must also be considered. In Figure $5 \mathrm{~A},(2 \cdot \mathrm{Ca}+\mathrm{Na}) / \mathrm{Ti}$ vs. $\mathrm{Al} / \mathrm{Ti}$, the slope is equal to $(2 \cdot \Delta \mathrm{Ca}+\Delta \mathrm{Na}) / \Delta \mathrm{Al}$. Plagioclase and augite are the only phases with significant $\mathrm{Ca}, \mathrm{Na}$, or $\mathrm{Al}$, but plagioclase has five cations per formula unit, and augite has only four. As a result, the change in Ca resulting from augite fractionation has to be multiplied by $5 / 4$ so that the ratio of minerals obtained from the slope remains in cation percent. If we assume an augite composition of $\mathrm{Ca}_{0.67}\left[\mathrm{Fe}+\mathrm{Mg}_{1.33} \mathrm{Si}_{2} \mathrm{O}_{6}, \Delta \mathrm{Ca}=(5 / 4 \cdot 2 / 3 \cdot \mathrm{Xcpx}+\mathrm{Xan}), \Delta \mathrm{Na}\right.$ $=\mathrm{Xab}$, and $\Delta \mathrm{Al}=(2 \cdot \mathrm{Xan}+\mathrm{Xab})$. Therefore:

slope $=[2 \cdot(5 / 4 \cdot 2 / 3 \cdot \mathrm{Xcpx}+\mathrm{Xan})+\mathrm{Xab}] /[2 \cdot \mathrm{Xan}+\mathrm{Xab}]$

slope $=[1.6667 \cdot \mathrm{Xcpx}+2 \cdot \mathrm{Xan}+\mathrm{Xab}] /[2 \cdot \mathrm{Xan}+\mathrm{Xab}]$

Normalizing to $1 \mathrm{Xcpx}$ :

slope $=[\mathrm{Xcpx}+1.2 \cdot \mathrm{Xan}+0.6 \cdot \mathrm{Xab}] /[1.2 \cdot \mathrm{Xan}+0.6 \cdot \mathrm{Xab}]$

Replacing Xan with $(1-\mathrm{Xcpx}) \mathrm{AN}$ and $\mathrm{Xab}$ with $(1-\mathrm{Xcpx}) \mathrm{AB}$ and rearranging:

$\mathrm{Xcpx}=[($ slope -1$) \cdot(1.2 \cdot \mathrm{AN}+0.6 \cdot \mathrm{AB}] /[1+($ slope -1$) \cdot(1.2 \cdot \mathrm{AN}+$ $0.6 \cdot \mathrm{AB})]$

where $\mathrm{AN}$ and $\mathrm{AB}$ refer to the anorthite and albite contents of the fractionated plagioclase $(\mathrm{AN}+\mathrm{AB}=1)$. 